\title{
Obesity and Hypertension among Adults in Mantang Integrated Health Services for Non-communicable Diseases, Bintan District, Riau Islands
}

\author{
Leni Jayanti \\ Department of Epidemiology, Faculty of Public Health \\ Universitas Indonesia \\ Depok, Indonesia \\ ewarsbintan@gmail.com
}

\begin{abstract}
Hypertension is called as the "silent killer" because people with hypertension often do not know themselves have hypertension. This condition which is known as uncontrolled hypertension will cause various complications, especially stroke, heart attack, and kidney failure which can lead to death. Obesity is a risk factor that is closely related to the incidence of hypertension. This study aims to examine the association between obesity with hypertension in Mantang Integrated Health Services for Non-communicable Diseases, Bintan District, Riau Islands Province.This is cross-sectional study analyzing data from Mantang Integrated Health Services for Non-communicable diseases year 2017. Collected samples were 330 adults aged 18 years or more. A dependent variable is hypertension. The main independent variable was obesity and covariate variables were age, sex, education, work status, family history of hypertension, central obesity, smoking, physical activity, and fiber consumption. This study performed logistic regression for multivariate analysis. The results of this study indicated that $23.9 \%$ of subjects were hypertension, and $42 \%$ were obese. Obese subjects were 2.5 (95\% CI: 1.21-4.89) times more likely to have hypertension than non-obese individuals. The odds ratio is calculated after adjusting the confounding effect for age, central obesity, fiber intake, and physical activity.Obesity is a significant risk factor associated with hypertension among adults in Integrated Health Services for Noncommunicable Diseases. Therefore, the effort to prevent hypertension is needed especially in the obese group.
\end{abstract}

Keywords - Hypertension; Obesity; Posbindu

\section{INTRODUCTION}

Hypertension is a condition in which the pressure on the blood vessel increases persistently due to forces caused by blood pressure against the artery wall when pumped by the heart [1]. According to Joint National Committee (JNC), VII 2003, adults hypertension is indicated by an increase in systolic blood pressure $\geq 140 \mathrm{mmHg}$ and/or diastolic blood pressure $\geq 90 \mathrm{mmHg}$ [2].

World Health Organization (WHO) reported an estimated 1 billion adult suffered from hypertension in the world and complications of hypertension cause 9.4 million deaths worldwide each year [3]. In Indonesia, the prevalence of hypertension is still quite high. Results of Basic Health Research/ Riset Kesehatan Dasar (Riskesdas) in 2013 showed the prevalence of hypertension in Indonesia is $26.5 \%$ population [4].

Riau Island is one of the provinces where hypertension prevalence is high. According to Riskesdas data in 2013, hypertension prevalence in Riau Islands defined by on location measurement was $22.4 \%$, whereas hypertension prevalence defined by self-report diagnosed or currently taking medication was only $8.8 \%$ [4]. This data indicates a notable number of uncontrolled hypertension. This is because hypertension presence is often without symptoms, so the patient does not know he is suffering from hypertension. Therefore, hypertension disease is often referred to as the silent killer [5]. Uncontrolled hypertension will lead to various complications, especially heart attacks, strokes, kidney disorders, and blindness [2].

Increased prevalence of hypertension is associated with the lifestyles such as consuming high-fat and high-calorie foods, lack of physical activity, smoking, high-sodium diet, and alcohol consumption [5]. Obesity is a risk factor that is closely related to the incidence of hypertension. Directly, obesity can lead to hypertension through increased cardiac output because the greater of body mass, the more the amount of blood circulating so that cardiac output increases. Indirectly, it stimulates sympathetic nervous system activity and Renin Aldosterone System (RAAS) by hormone aldosterone that is associated with Body Mass Index (BMI) and abdominal circumference [6].

Studies conducted by the Framingham Heart Study showed obese individuals at $2.2-2.6$ times more likely to get hypertension than non-obese individuals [7]. Sulastri et al found people with obesity were 1.8 times at higher risk of suffering from hypertension than people who were not obese [8]. According to of Riskesdas data, the prevalence of obesity among adults in Indonesia increases from 2017 to 2013. The prevalence of obesity in men increased from $13,9 \%$ in 2007 to $19,7 \%$ in 2013, while in women increased from 13,9\% in 2007 to $32,9 \%$ in 2013 [4], [9]. While the prevalence of obesity in Riau Island is $18,2 \%$, higher than the national prevalence of $15,4 \%$ [4].

Based on health profile data of Bintan District Health Office (DHO) in 2016, hypertension was ranked as the first of the top ten diseases in Bintan district, which were 5,980 cases (52.8\%). The highest number of hypertensive patient visitors was at 
Mantang Community Health Center (Puskesmas), at 74\% [10]. This study aims to evaluate the association between obesity with hypertension in Mantang Subdistrict, Bintan District.

\section{METHODS}

This study used a cross-sectional study design to evaluate the association between obesity and hypertension among adults (age $\geq 18$ years old) in Mantang Community Health Service for Non-communicable diseases. This study used secondary data from Integrated Health Services for Non-communicable Diseases report by Mantang Community Health Services in August 2017. The study population was all adult population aged $\geq 18$ years recorded in Mantang Integrated Health Services for Non-communicable Diseases report in August 2017. This study obtained 330 samples.

The dependent variable is hypertension and the main independent variable is obesity. Other independent variables (covariate) of this study were age, sex, education level, work status, family history of hypertension, central obesity, smoking, physical activity, and fiber consumption.

Hypertension data obtained from measurement of systolic and diastolic blood pressure using digital tensimeter. Data were calculated from the average of twice taken measurement. Hypertension status was determined according to a criterion of JNC VII 2003, that is systolic blood pressure $\geq 140 \mathrm{mmHg}$ and or diastolic blood pressure $\geq 90 \mathrm{mmHg}$. Obesity data is obtained from the calculation of BMI which describes the nutritional status of the population, that is based on the ratio of body weight and height squared. By referring to WHO criteria for Asia Pacific region, obese is defined as BMI $\geq 25 \mathrm{~kg} / \mathrm{m}^{2}$ and not obese as BMI $<25 \mathrm{~kg} / \mathrm{m}^{2}$ [11]

Age is grouped into 18-39 years and $\geq 40$ years. Education level is grouped into high and low education. High is defined as those who complete at least senior high school, other those are defined as low education. Work status is grouped into working and not working. Smoking habits grouped into smoking and not smoking, physical activity grouped into active and inactive, fiber consumption grouped into two enough and less.

This study performed the univariate, bivariate and multivariate analysis. To assess the confounding effect of obesity on hypertension, the adjusted odds ratio was calculated using logistic regression. The backward method was used to obtain the final model of multivariate analysis with logistic regression. Interaction test was conducted to determine the interaction between covariate variable with obesity.

\section{RESULTS}

Mantang Subdistrict consists of four villages namely Mantang Lama Village, Big Mantang, Mantang Baru, and Dendun. Integrated Health Services for Non-communicable Diseases has been running in Mantang Subdistrict since 2016 with the establishment of a basic Integrated Health Services for Non-communicable Diseases in Dendun village. In 2017, Integrated Health Services for Non-communicable Diseases developed in other villages so that currently there are 4 Basic Integrated Health Services for Non-communicable Diseases in
Mantang Subdistrict. Although Basic Integrated Health Services for Non-communicable Diseases does not perform blood sugar and cholesterol test. However, Integrated Health Services for Non-communicable Diseases in Mantang has the complete report for basic risk factors which can be used to assess the relation between obesity with hypertension.

The proportion of hypertension of those who came to Integrated Health Services for Non-communicable Diseases in Mantang was $23.9 \%$ (Table 1).

TABLE I

PROPORTION OF HYPERTENSION AMONG INTEGRATED HEALTH SERVICE VISITORS IN MANTANG YEAR 2017

\begin{tabular}{|l|c|c|}
\hline Status & Number & Percentage (\%) \\
\hline Hypertensive & 79 & 23.9 \\
\hline Normotensive & 251 & 76.1 \\
\hline Total & 330 & 100 \\
\hline
\end{tabular}

There was $42.2 \%$ of Mantang Posbindu visitors who were obese. That is, almost half of the people who come to Posbindu in Mantang suffered from obesity (Table 2.)

TABLE II.

PROPORTION OF OBESITY AMONG INTEGRATED HEALTH SERVICES VISITORS IN MANTANG YEAR 2017

\begin{tabular}{|l|c|c|}
\hline Obesity status & Number & Percentage (\%) \\
\hline Obese & 139 & 42.2 \\
\hline Non-obese & 191 & 57.8 \\
\hline Total & 330 & 100 \\
\hline
\end{tabular}

Bivariate analysis was performed to examine the association between obesity and covariate variables (age, sex, education level, work status, family history, central obesity, smoking, physical activity, fiber consumption, and alcohol consumption) with hypertension. Table 3 shows the 79 subjects with hypertension, $50(63.3 \%)$ were obese. In comparison to normotensive subjects, there were only $35 \%$ subjects who were obese. Chi-square test showed the relation between obesity and hypertension was statistically significant (OR: 3.14; 95\% CI: 1.79-5.51).

TABLE III

ASSOCIATION BETWEEN OBESITY AND HYPERTENSION AMONG INTEGRATED HEALTH SERVICES VISITORS IN MANTANG YEAR 2017

\begin{tabular}{|l|c|c|c|c|}
\hline & \multicolumn{2}{|c|}{ Hypertension } & P & OR \\
\hline $\begin{array}{l}\text { Obesity } \\
\text { Status }\end{array}$ & $\begin{array}{c}\text { Yes } \\
\mathbf{n}(\boldsymbol{\%})\end{array}$ & $\begin{array}{c}\text { No } \\
\mathbf{n}(\%)\end{array}$ & value & $\mathbf{9 5 \%}$ CI \\
\hline Obese & $50(63.3)$ & $89(35.5)$ & & 3.14 \\
\hline Non-obese & $29(36.7)$ & $162(64.5)$ & 0.000 & $(1.79-5.51)$ \\
\hline
\end{tabular}

This study identified several statistically significant covariate factors between hypertensive and normotensive individuals as shown in Table 4 . The proportion of subjects aged $\geq 40$ years was greater among hypertensive individuals $(74.7 \%)$ than normotensive individuals (35.9\%). The 
proportion of individuals with central obesity was greater in hypertensive individuals $(65.8 \%)$ than normotensive individuals $(45 \%)$. Furthermore, the proportion of individuals with a family history of hypertension was greater in the normotensive group $(14.7 \%)$ than in the hypertensive group $(5.1 \%)$.

TABLE IV

COVARIAT RISK FACTORS ASSOCIATED WITH HYPERTENSION AMONG INTEGRATED HEALTH SERVICES VISITORS IN MANTANG YEAR 2017

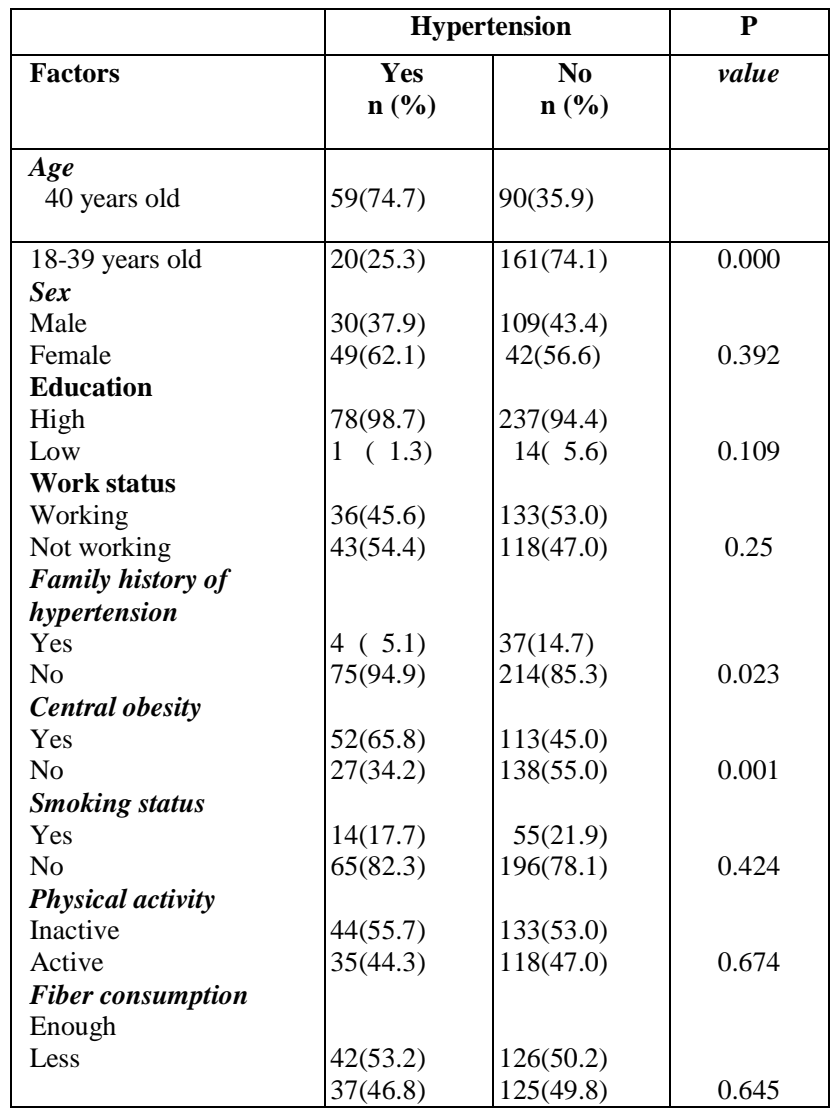

Interaction test showed no interaction between covariate risk factors and obesity ( $>>0.05)$. All covariate risk factors were incorporated into full multivariate models with logistic regression tests as presented in the following Table 5.

TABLE V

FULL MODEL OF LOGISTIC REGRESSION ANALYSIS OF OBESITY RELATION WITH HYPERTENSION

\begin{tabular}{|l|c|c|c|c|}
\hline Variable & Coeff & P & OR & 95\% CI \\
\hline Obesity & 0.958 & 0.005 & 2.61 & $1.33-5.12$ \\
\hline Age & 1.467 & 0.000 & 4.34 & $2.39-7.88$ \\
Sex & -0.29 & 0.547 & 0.75 & $0.29-1.92$ \\
\hline Education & 0.513 & 0.652 & 1.67 & $0.18-15.48$ \\
Work status & -0.34 & 0.763 & 0.71 & $0.07-6.83$ \\
\hline Family history & -0.78 & 0.184 & 0.45 & $0.14-1.45$ \\
\hline Central obesity & 0.157 & 0.667 & 1.17 & $0.57-2.39$ \\
Physical Activity & -0.63 & 0.572 & 0.53 & $0.06-4.74$ \\
Smoking & -0.06 & 0.874 & 0.94 & $0.41-2.12$ \\
Fiber consumption & 0.344 & 0.255 & 1.14 & $0.78-2.55$ \\
\hline
\end{tabular}

To assess whether there are covariate variables that become confounding, then used the backward method by issuing one by one covariate variable which has the OR value nearest 1 . If the OR difference between the before and after the covariate variable is greater than $10 \%$, then the variable is stated confounding and must remain in the model, and if less than $10 \%$, then the covariate variable is not confounding and excluded from the model.

The end result of the logistic regression test (Table 6) shows that the variables of age, central obesity, fiber consumption, and physical activity are confounding factors in the association between obesity and hypertension. Obesity was a significant risk factor associated with hypertension (OR: 2.53, 95\% CI: 1.31-4.89), after controlled by age, central obesity, physical activity, and fiber consumption.

TABLE VI

FINAL MODEL OF LOGISTIC REGRESSION ANALYSIS OF ASSOCIATION BETWEEN OBESITY AND HYPERTENSION

\begin{tabular}{|l|c|c|c|}
\hline \multicolumn{1}{|c|}{ Variable } & Coeff & OR & 95\% CI \\
\hline Obesity & 0.927 & 2.53 & $1.31-4.89$ \\
\hline Age & 1.543 & 4.67 & $2.61-8.39$ \\
\hline Central obesity & 0.298 & 1.35 & $0.69-2.64$ \\
Fiber consumption & 0.301 & 1.35 & $0.77-2.36$ \\
Physical activity & -0.109 & 0.89 & $0.49-1.63$ \\
\hline
\end{tabular}

\section{DISCUSSION}

This study has several limitations which can not be avoided so can affect the results of research. The data used in this study was the secondary data from Integrated Health Service for Non-communicable Diseases report. Therefore, the researcher could not control the quality data directly, and the variables studied limited to the available data. The variables analyzed in this study only the variables available data from Integrated Health Service for Non-communicable Diseases report. Generalization of the study findings might be limited due to the research used the data with nonprobability sampling method.

Obesity is a risk factor that is strongly associated with hypertension and cardiovascular disease [7], [12], [13]. Several mechanisms explain how obesity increases blood pressure in the arteries [14]. Obesity can directly lead to hypertension because of the increased cardiac output. The greater the body mass resulted from the more amount of blood circulation which leads to an increase in cardiac output. Indirectly, obesity activates the sympathetic nervous system and reninangiotensin-aldosterone system. Obesity is also associated with endothelial dysfunction and renal function abnormalities that may play a role in the development of hypertension [6], [14].

This study found $23.9 \%$ of Integrated Health Service for Non-communicable Diseases visitors in Mantang Subdistric suffered from hypertension. This figure is higher than hypertension prevalence of Bintan District (20.5\%) as reported by Riskesdas year 2013 [4]. This shows that there is a tendency of an increasing hypertension cases in Bintan District, especially at Mantang Subdistrict. Earlier research revealed that the rapidly increasing prevalence of hypertension is closely 
related to lifestyle changes especially in the increasing number of obesity [12], [15]. This is aligned with this study results which reported that almost half $(42 \%)$ of the adults who came to Integrated Health Services for Non-communicable Diseases in Mantang subdistrict is obese.

The proportion of hypertension was higher in obese individuals $(63.3 \%)$ than nonobese individuals. This is in line with research conducted by Rahajeng et al (2009) in the adult population in Indonesia which states that the proportion of obesity in hypertensive individuals is $25.9 \%$ higher than nonhypertensive individuals (15.2\%) [16] Similarly, Sulastri et al's whose study on Minangkabau ethnic community in Padang city also found more than half $(56.6 \%)$ of hypertensive individuals on her study were obese [8].

The final result of logistic regression analysis showed that obesity was significantly associated with hypertension after being controlled by age, central obesity, physical activity, and fiber consumption. Obese individuals were 2.53 more likely to be hypertensive compared to non-obese individuals. Framingham Heart Study showed similar results. Those whose BMI $\geq 25 \mathrm{~kg} / \mathrm{m}^{2}$ were 2.2 times for female and 2.6 times for male more likely to have hypertension than those whose BMI $<25 \mathrm{~kg} / \mathrm{m}^{2}$ [7]. Similarly, a 12-year longitudinal study on 6,096 individuals in China found that obese subjects were 2.8 times more likely to suffer from hypertension compared to non-obese individuals [17].

Of the hypertension modifiable risk factors included in this study (smoking, central obesity, physical activity, and fiber consumption), obesity is the most significant risk factor associated with hypertension. However, the potential risk factors for confounding in obesity and hypertension relationships such as fat consumption and sodium intake can not be assessed in this study. Several previous studies have suggested that a diet high in fat and high in sodium is a risk factor that independently affects hypertension [18]-[20].

Age is also a significant risk factor associated with hypertension in this study, where individuals who were $\geq 40$ years more likely to be hypertensive than individuals aged 1839 years. However, age is an unmodifiable risk factor. Riskesdas 2013 reported the increase of hypertension prevalence started at the 35-44 years age group. On the other hand, hypertension prevalence among those above 55 years reaches $45 \%$ [4].

\section{CONCLUSIONS}

This study found obesity is a significant risk factor associated with hypertension. Obese individuals were 2.5 times more likely to have hypertension than nonobese individuals. Efforts to prevent and control hypertension in Mantang Subdistrict needs to target obese individuals. There is need to increase promotive and preventive approach such as providing communication, information and education on the importance of weight control by maintaining the balanced diet, consuming adequate fruits and vegetables, reducing fat consumption, performing the regular physical activity and having regular health checks in Integrated Health Services for Noncommunicable Diseases where available.

\section{ACKNOWLEDGMENT}

This research uses data from Mantang Integrated Health Service for Non-communicable Diseases/ Pos Pembinaan Terpadu Penyakit Tidak Menular (Posbindu PTM) report. I thank the Head of Bintan District Health Office and Mantang Community Health Service who has allowed the use of Mantang Integrated Health Service for Non-communicable Diseases data to be analyzed in this research.

\section{REFERENCES}

[1] WHO, "Hypertension," WHO, 2017. [Online]. Available: who.int/topics/hypertension/en/. [Accessed: 15-Nov-2017].

[2] Kemenkes RI, Pedoman Teknis Penemuan dan Tatalaksana Hipertensi, Revisi 201. Jakarta: Direktorat Pengendalian Penyakit Tidak Menular, 2013.

[3] WHO, "Q\&As on hypertension," 2015. [Online]. Available: http://www.who.int/features/qa/82/en/. [Accessed: 22-Nov-2017].

[4] Kemenkes RI, Riset Kesehatan Dasar 2013. Jakarta: Badan Penelitian dan Pengembangan Kesehatan Kementerian Kesehatan RI, 2013.

[5] WHO, "World Health Day 2013," A Glob. Br. Hypertens., p. 9, 2013.

[6] S. Sheps, Mayo clinic hipertensi, mengatasi tekanan darah tinggi. Jakarta: Intisari Mediatama, 2005.

[7] P. W. F. Wilson, R. B. D’Agostino, L. Sullivan, H. Parise, and W. B. Kannel, "Overweight and Obesity as Determinants of Cardiovascular Risk," Arch. Intern. Med., vol. 162, no. 16, p. 1867, 2002.

[8] D. Sulastri, Elmatris, and R. Ramadhani, "Hubungan Obesitas dengan Kejadian Hipertensi pada Masyarakat Etnik Minangkabau di Kota Padang," Maj. Kedokt. Andalas, vol. 36, no. 2, pp. 188-199, 2012.

[9] Depkes RI, Laporan Riskesdas 2007. Jakarta: Badan Penelitian dan Pengembangan Kesehatan Kementerian Kesehatan RI, 2008.

[10]Dinkes Kabupaten Bintan, Profil Kesehatan Kabupaten Bintan Tahun 2016. Sunram Dinkes Kabupaten Bintan, 2017.

[11] WHO, "The Asia-Pacific perspective: redefining obesity and its treatment," Health Communications Australia Pty Limited, Sydney, 2000.

[12] Doll, P. F, B. P, B. M, and W. V., "Bodymass index, abdominal adiposity and blood pressure: consistency of their association across developing and developed countries.," Int. J. Obes. Relat. Metab. Disord., vol. 26, pp. 4857, 2002.

[13]Luke A, Adeyemo A, Kramer H, Forrester T, and Cooper RS, "Association between blood pressure and resting energy expenditure independent of body size," Hypertension, vol. 43, p. 555, 2004.

[14] K. Rahmouni, M. L. G. Correia, W. G. Haynes, and A. L. Mark, "Obesityassociated hypertension: New insights into mechanisms," Hypertension, vol. 45, no. 1, pp. 9-14, 2005.

[15] H. Wang, D. S, Z. F, and P. BM, "Trends in the distribution of body mass index among Chinese adults, aged 20-45 years (1989-2000)," Int J Obes (Lond)., vol. 31, pp. 272-278, 2007.

[16]E. Rahajeng and S. Tuminah, "Prevalensi Hipertensi dan Determinannya di Indonesia," Maj Kedokt. Indones., vol. 59, no. 12, pp. 580-587, 2009.

[17] J. Niu and D. Seo, "Central obesity and hypertension in Chinese adults : A 12-year longitudinal examination," Prev. Med. (Baltim)., vol. 62, pp. 113$118,2014$.

[18] A. Sugiharto, "Faktor-Faktor Risiko Hipertensi Grade II," 2007.

[19] A. R. A. Emiria, "Asupan Protein, Lemak Jenuh, Natrium, Serat, Dan IMT Berkaitan Dengan Tekanan Darah Pasien Hipertensi Di RSUD Tugurejo Semarang," Artik. Penelit., vol. 1, pp. 22-23, 2012.

[20]L. Atun, T. Siswati, and W. Kurdanti, "Sources of Sodium Intake, Sodium Potassium Ratio, Physical Activity, and Blood Pressure of Hypertention Patients Dinas Kesehatan Kabupaten Sleman ta-," Mgmi, vol. 6, no. No. 1, pp. 63-71, 2014. 